\title{
(E); $\begin{aligned} & \text { Central European } \\ & \text { Economic Journal }\end{aligned}$
}

ISSN: 2543-6821 (online)

Journal homepage: http://ceej.wne.uw.edu.pl

\author{
Justyna Zalewska, \\ Natalia Nehrebecka
}

\section{Liquidity and solvency of a company and the rate of return - an analysis of the Warsaw Stock Exchange}

To cite this article

Zalewska, J., \& Nehrebecka, N. (2019). Liquidity and solvency of a company and the rate of return - an analysis of the Warsaw Stock Exchange.

Central European Economic Journal, 6(53), 199-220.

DOI: 10.2478/ceej-2019-0013

↔ To link to this article: https://doi.org/10.2478/ceej-2019-0013 
Justyna Zalewska
Faculty of Economic Sciences, University of Warsaw , Warsaw, Poland,

\title{
Natalia Nehrebecka
}

Faculty of Economic Sciences, University of Warsaw , Warsaw, Poland, corresponding author: nnehrebecka@wne.uw.edu.pl

\section{Liquidity and solvency of a company and the rate of return - an analysis of the Warsaw Stock Exchange}

\begin{abstract}
The purpose of the article is to analyse the impact of various financial ratios used to evaluate a company's liquidity and solvency on the rates of return on the shares of companies listed on the Warsaw Stock Exchange. In the context of developing countries, the relationship between liquidity and solvency on the one hand and the return on equity on the other is still not clear. Poland is the most economically developed country in Central and Eastern Europe. A thorough analysis is necessary to take appropriate action and introduce adequate regulations in the country, as well as to create the foundation for researching other economies in this region. In addition, this article includes new estimators that have not yet been taken into account but that may affect the rates of return, which will contribute to the literature on the subject and to the development of knowledge on the volatility of returns on shares. In the study, we have calculated the time-varying beta coefficients of the capital asset pricing model (CAPM) model and analysed portfolios based on three liquidity ratios and four solvency ratios, which were computed using the CAPM, Fama-French and Carhart models. The empirical study described in the article focuses on companies listed on the Warsaw Stock Exchange in the period from 1 January 1999 to 30 June 2013. Regressions were estimated by the least-squares method and by quantile regression. Based on the results, it was found that listed companies at risk of bankruptcy are able to meet their shortterm liabilities. Liquidity and solvency measured by financial ratios significantly affect the sensitivity of the rate of return on shares to the risk factors expressed in the CAPM, Fama--French and Carhart models.
\end{abstract}

\section{Keywords}

liquidity | solvency | asset pricing models | CAPM | portfolio analysis

\section{JEL Codes}

$\mathrm{G} 12, \mathrm{G} 32, \mathrm{G} 33, \mathrm{G} 35$

\section{Introduction}

The volatility of rates of return and its determinants are very often analysed in the available literature. In the course of research, the capital asset pricing model (CAPM) model, which tests the sensitivity of a given asset to market risk, was created. Then, its extensions appeared, the most popular of which are the FamaFrench and Carhart models. They usually provide a satisfactory explanation of the behaviour of rates of returns, but the obtained results show that there is an additional factor that should be taken into account. One of the ideas for augmenting business asset pricing models is incorporating the company's liquidity or solvency into analysis.

Based on the literature review, there are studies on the volatility of returns on shares that take into consideration the liquidity or solvency of a firm. However, these analyses often centre on stock exchanges in the United States and are usually very advanced due to the degree of development of the US economy. Current studies also verify new estimators that may affect the rates of return and that have not been used in previous research. Conclusions from research on the US stock market are usually transferred to less-economically developed countries, which 
creates another group of analyses. Quite often, they focus on gradually extending the research carried out so far by verifying the effects identified in the United States. There is also a category of research studies on emerging markets, which most often deal with pinpointing basic correlations. With regard to the analyses of the Warsaw Stock Exchange, there is still room for further research in this field. Conclusions from the analysis of the results of asset valuation models differ depending on the adopted measure of liquidity or solvency (Lischewski and Voronkova, 2012). It is, therefore, worth performing an analysis of the feasibility of hitherto-untested indicators.

The purpose of the article is to analyse the influence of various financial ratios for the assessment of a company's liquidity and solvency on the rates of return on stocks of the companies listed on the Warsaw Stock Exchange. We utilised liquidity ratios such as the current liquidity ratio, the quick ratio and the working capital ratio. We also adopted four solvency ratios: Altman $\mathrm{Z}$-score, the debt ratio, the leverage ratio and the fixed asset coverage ratio. ${ }^{1}$ In the case of developing countries, the relationship between liquidity and solvency on the one hand and the return on equity on the other is still unclear. Poland is the most economically developed country in Central and Eastern Europe. A thorough analysis is required to take appropriate action and introduce necessary regulations in the country, as well as to create the basis for researching other economies in this region.

The empirical study presented in the article focuses on companies listed on the Warsaw Stock Exchange in the period from 1 January 1999 to 30 June 2013. It consists of two stages. The first step involves presenting the behaviour of mean and median values of time-varying beta coefficients of the CAPM model across the quantiles of the solvency and liquidity ratios. The second step aims to illustrate the results obtained from the CAPM, Fama-French and Carhart asset pricing models according to the portfolios built on the basis of liquidity and solvency ratios. The methodology adopted in the article is classical regression estimated by the least-squares method and quantile regression.

In the empirical study, two hypotheses were assumed. The first main hypothesis was that

1 Gabrusiewicz (2014) discusses the debt rate and the asset coverage ratio as estimators of a company's solvency and financial independence, respectively. The leverage ratio is applied as a measure of solvency in Medhat's research (2014). companies at risk of bankruptcy are able to meet their short-term obligations. This relationship was proved by Medhat (2014) for companies listed on American stock exchanges. Poland is at a much lower level than the United States in terms of economic development, but as mentioned earlier, it is a leader in the region of Central and Eastern Europe. Therefore, it seems interesting to check whether the correlation observed on the US stock exchanges is true for the Warsaw Stock Exchange.

The second hypothesis was that liquidity and solvency measured by financial ratios significantly affect the sensitivity of the rate of return on shares to risk factors expressed in the CAPM, Fama-French and Carhart models. The investigations of Li et al. (2014) on the Tokyo Stock Exchange, Vu et al. (2015) on the Australian market, Cotter et al. (2015) on the London Stock Exchange, Batten and Vo (2014) on Vietnam, and Minović and Živković (2012) on Serbia, as well as the studies of the American stock exchanges, suggest that there is no reason to reject the above hypothesis. Therefore, the correlation seems to occur regardless of the degree of the country's economic development and of its specific nature. The suspicion that the described relationship is also valid for Poland is, therefore, vindicated and worth examining.

The article is divided into the following sections. Section 2 outlines the theoretical issues in the area of rates of return, of asset-pricing methods, as well as the liquidity and solvency of a firm. The next section (Section 3) presents research to date on the effect of liquidity and solvency on rates of return on equity of companies. The last section (Section 4) offers an examination of the impact of liquidity and solvency on the rates of return on shares of companies listed on the Warsaw Stock Exchange. It also contains a description of the data and the utilised methodology. Finally, the main conclusions and a summary of the article are presented.

\section{Theoretical foundations of research on the rate of return on shares}

The output of economic theory in the field of liquidity and solvency of a firm, methods of asset valuation and explanation of returns on shares is copious and still growing. In order to locate our considerations within 
the delineated economic concepts, this section lists the most important issues related to the subject of analysis.

While presenting the rates of return on shares, it is impossible not to refer to the risk involved in them. This risk can have two dimensions (Dębski, 2014). One of them is the risk arising from the hazards that threaten a specific company and are characteristic only for it and, possibly, several of its competitors. This aspect is called idiosyncratic risk, and its elimination is possible through portfolio diversification. There is also a risk that cannot be removed by any measure because it stems from macroeconomic factors affecting all companies that operate within a given economic system. It is defined as systemic risk, and every investor is exposed to it. These issues underlie the pricing of assets, and thus, their clarification is necessary to define asset valuation models.

From an investor's perspective, it is very important to be aware of the factors affecting the rates of return on a company's stocks. The parameters that are often mentioned in this context are the company's liquidity and solvency. It should be remembered that examining a company's situation in this respect requires a clear definition of liquidity and solvency. The distinction between financial liquidity, solvency and trading liquidity is crucial here. ${ }^{2}$ These terms should not be used interchangeably because they have different meanings.

As the subject of asset valuation was gaining traction, various models explaining the behaviour of rates of return on shares appeared in economic theory. The basic tool here is the CAPM model, on the basis of which more advanced versions such as the FamaFrench or Carhart model were later built. In addition, the CAPM model modified by incorporating a ratio of liquidity and a Fama-MacBeth estimation method ${ }^{3}$ stand out.

2 In the context of terminology, Jachna and Sierpińska (2004) additionally distinguish liquidity of assets, which is defined by the possibility of quick exchange of individual elements of the company's assets for cash. Liquidity of assets is an aspect that affects the assessment of a company's financial liquidity.

3 The CAPM model extended by solvency (LCAPM) and the Fama-MacBeth estimation method are not used in our empirical study, but they appear in the literature. LCAPM has been used in the analysis of Lischewski and Voronkova (2012), Hearn (2014), Minović and Živković (2012), Bradrania and Peat (2013) and Bradrania and Peat (2014). The FamaMacBeth estimation method can be found, among others, in the works of Medhat (2014), Huffman and Moll (2012), Wang (2012) and Cotter et al. (2015). Hence, it is important to present the theory behind both concepts.

\section{Impact of liquidity on rates of return from equity in the literature}

The analysis of factors affecting the rate of return on company equity has been very often performed in the available literature. The desire to explore this issue is motivated by looking for areas that can contribute to improving the return on equity. The relationships between risk ratios, the company's solvency ratios and the company's individual characteristics on the one hand and the rate of return on equity on the other are most often scrutinised. Most of the authors draw on Fama and French's theory and on the CAPM model.

The majority of studies on this topic attempt to augment the range of explanatory factors by adding a new estimator related to either risk or, e.g., the condition of the company to the existing theory. Most often, in the initial phase, the impact of the new indicators is tested on sample companies listed on American stock exchanges. This has to do with the highly developed nature of the US economy, the size of the US stock exchanges and their long history. Regardless of the results of these analyses, and regardless of whether or not they identify a significant relationship, based on such research, new factors are incorporated into studies on countries characterised by lesser economic development than the United States. There is also a group of studies that focus on investigating the basic relationships for areas or time periods not yet considered in the available literature.

In order to discuss the subject of the rate of return on equity in more detail, this section provides an overview of selected articles, which are divided into four groups. The first of these covers publications about companies listed on stock exchanges located in the United States. The second includes research conducted on data from the London, Singapore, Australian and Japanese stock exchanges. They are less advanced than the analyses in the first group; however, they also broaden the set of factors studied so far or imitate the studies concentrating on the United States. The third group comprises articles about Taiwan, Vietnam, Nigeria and Serbia, which analyse more elementary dependencies. Finally, selected studies carried out so far on companies listed on the Warsaw Stock Exchange are additionally presented. 


\subsection{Research on the US stock exchanges}

Companies listed on stock exchanges located in the United States comprise one of the most frequently analysed topics. Despite the wealth of available literature, researchers are constantly trying to expand the scope of research with new variables or indicators. A popular and widespread trend in research on the rate of return on equity of a firm is considering the firm's liquidity or solvency ratio. Garlappi and Yan (2011) entered a company's financial liabilities into the equity pricing model and checked how the likelihood of shareholders regaining capital affects the relationship between returns on equity and the probability that the firm will default, measured as the Expected Default Frequency. Lin et al. (2011) focused on verifying the statistical significance of the correlation between the ratio of systemic liquidity risk and the rate of return on stocks. The risk calculated in this analysis is defined as the odds of a decrease in the value of stocks at a time when the aggregate market liquidity falls, while the liquidity ratio is either the Amihud or the Pastor-Stambaugh ratio. Palazzo (2012) presented a study on the construction of a model explaining the effect of correlations between cash flows and the source of aggregate risk on the optimal amount of a company's cash holdings. Acharya et al. (2012) linked cash reserves to credit risk and demonstrated that the precautionary principle has the highest priority even for companies that issue stocks. Huffman and Moll (2012), when examining the rate of return on a firm's equity, treated risk differently compared to the authors of the previously mentioned study. The authors scrutinised the impact of asymmetrical risk ratios, such as value at risk (VaR) and the home run ratio, on equity returns.

Wang (2012), on the other hand, looked at the effect of corporate liquidity ${ }^{4}$ on the return on equity. One of the objectives of that study was to determine whether the solvency ratio it adopts yields different outcomes when explaining the level of return on equity than do the size factor of the company and the ratio of the company's book value to its market value. Bradrania and Peat (2013) broadened the current analyses by a larger historical context by examining the relationships between solvency and return on equity of companies for the data of the years

4 Corporate liquidity is defined as the ratio of the amount of cash held by a company $i$ in month $t$ to the total assets owned by the company $i$ in month $t$. A high value of the ratio means high liquidity of the company, while a low value indicates low solvency.
1926-2008. The authors defined the liquidity measure as a stock characteristic and applied the Effective Tick4 (henceforth EFFT) EFFT estimator based on daily transaction data, as developed by Holden (2009). Bradrania and Peat (2014) determined whether, in research on the rate of return on company equity, liquidity should be treated as a stock characteristic or perhaps as a measure attributed to the entire market. Friewald et al. (2014), on the other hand, attempted to estimate the risk premium for American companies and to tie those values to the excess return on equity. The authors observed a positive correlation between the risk premium measure and return on capital. Medhat (2014) demonstrated that a company's cash resources can balance low returns on venture capital. In contrast to the available literature on the subject, which mainly revolves around the theory of capital structure, Medhat explored the issue of maintaining a level of cash sufficient to minimise the risk of loss of the company's liquidity. Park (2015) sparked a discussion on the impact of the value of stocks issued by a company on the profitability of its equity. In other US articles, Amihud's estimator (2002) has been a very frequently applied measure of liquidity. For example, Bali and Zhou (2016) adopted this measure as a control variable when testing the robustness of results according to the model specification method. The main purpose of the aforementioned research was to check whether market risk and economic uncertainty have a significant and positive effect on the rate of return on stocks.

The research outlined above was done on American stock exchanges. A recurring conclusion in most of the papers is that the common opinion about the higher solvency of companies with large cash resources is not true. It has been confirmed, however, that liquidity and solvency are important aspects that explain the behaviour of return on shares.

\subsection{Research on the stock exchanges in London, Singapore, Japan and Australia}

The second group of articles deals with the companies listed on the stock exchanges in London, Singapore, Japan and Australia. The reason for this grouping is the similar history of the stock exchange in each of these countries and a similar stage of economic development in each of them. A kind of reference point or inspiration for analyses carried out in 
this group is usually research based on American companies. So and Tang (2010) have studied data for the Singapore Stock Exchange in order to empirically verify the usefulness of the market beta coefficient, firm size measures, book-to-market $(\mathrm{B} / \mathrm{M})$ equity ratio and earnings-to-share ratio in explaining the returns on equity. Li et al. (2014) have analysed companies listed on the Tokyo Stock Exchange. Their main purpose has been to check whether the rate and risk of insolvency are echoed in the rates of return on equity of Japanese companies. Vu et al. (2015) have also investigated the relationship between solvency and returns on company equity, but for the Australian market. They have postulated that investors demand higher rates of return on shares for which solvency decreases as market liquidity decreases. Cotter et al. (2015) have examined companies listed on the London Stock Exchange. The goal of their study is to analyse how share-specific risk, called idiosyncratic risk, affects the rate of return on equity of a firm. What distinguishes this paper is that it includes the variable "response of excess return on equity" to systematic beta risk depending on whether the excess return on equity is positive or negative.

The studies presented above have been carried out in geographic areas with similar economic development. Most of them support the conclusion that liquidity and solvency significantly affect the rates of return. The liquidity-adjusted CAPM (LCAPM) model is found to be better suited to the data than the standard CAPM model. Moreover, in these papers, the most popular approach to asset pricing is the use of the CAPM and the Fama-French models.

\subsection{Research on the Nigeria, Serbia, Taiwan and Vietnam stock exchanges}

Another group of papers comprises research constructed on the basis of data from Nigeria, Serbia, Taiwan and Vietnam stock exchanges. In each of these four countries, the duration of the stock market has been quite similar and their economy can be described as a developing market. Studies centred on these countries mostly verify the basic relationships that work well in other markets. The scope of the analysis is quite narrow, and the articles are rather aimed at creating a base that allows more extensive research in the future.

Minović and Živković (2012) have tested the feasibility of using the Fama-French and Carhart models in illustrating and forecasting the behaviour of rates of return on capital for companies listed on the Serbian stock market. ${ }^{5}$ Considering the example of Taiwan, Chen and Lee (2013) have gauged whether the risk of a company's bankruptcy has a significant impact on its returns on equity and how the correlation between these variables is expressed in the FamaFrench and Carhart models. ${ }^{6}$ Moreover, Batten and Vo (2014) have performed an analysis of the companies listed on the Vietnam Stock Exchange. The main goal of their study is to examine the relationship between liquidity and stock returns in this market during the global financial crisis. The authors have identified a positive correlation between solvency and returns on capital. The reason for this state of affairs, in the researchers' opinion, is a smaller degree of integration of the emerging market with global markets. As in the case of other markets, in the case of Taiwan also, the relationship between the beta coefficient and returns on capital turns out to be negative and statistically significant. Hearn's study (2014) on Nigeria has shown the impact of company size and insolvency for all companies listed on the local stock exchange and across individual sectors.

It cannot be unequivocally concluded from the research on emerging markets, which has been presented in this section, whether liquidity and solvency significantly affect the rates of return. The significance of these factors depends on the market under analysis, as each of them has its own specific circumstances that can affect the results of the study.

\subsection{Research on the stock exchange in Poland}

Poland is often referred to as the most advanced emerging market among Central and Eastern

5 Before they conduct the analysis proper, they note several facts that are true for the local market. First of all, it is not developed, it has low liquidity and there is a lack of transparency in company reports. In addition, the history of the stock exchange itself and the historical scope of databases are small. These features mean that the relationships noted for the stock market in Serbia may differ from those observed in other markets.

6 At the beginning, it should be noted that the Taiwan stock market is significantly different from the markets of developed countries, because it is very volatile and is characterised by high liquidity. Transaction costs are also determined differently. In addition, the major group of players in Taiwan consists of small individual investors, who can often be described as uninformed. 
European countries. The beginnings of the Warsaw Stock Exchange date back to 1991, so the time period available for analysis is relatively short. Nevertheless, there are several studies worth mentioning in the context of analysing the volatility of returns on corporate shares. They constitute the last group of studies discussed here. Research is presented in the order from the least to the most complex.

The first study is by Czapkiewicz and Wójtowicz (2014), who have assessed the feasibility of the fourfactor Carhart model for data from the Warsaw Stock Exchange. The outcomes of empirical analysis reveal that the constructed portfolios are effective for the four-factor Carhart model. The next step in the analysis is to perform cross-sectional regression for these portfolios. Here, only the Carhart model is estimated. It turns out that only the market factor and the momentum factor are statistically significant in this regression. Despite the insignificance of the company size and capitalisation parameters, their explanatory value measured with the $R^{2}$ ratio is $60 \%$ for the model analysing the size-value portfolios and $73 \%$ for the size-momentum portfolios. As the authors have concluded, the momentum effect dominates the company size effect and its capitalisation when explaining the volatility of rates of stock returns of companies listed on the Warsaw Stock Exchange.

Waszczuk (2013) has conducted a more extensive analysis of the volatility of rates of return on shares for Poland. Noticing the shortage of current analyses on share pricing trends in the emerging markets, the author has filled this gap by deciding to examine stock pricing in the period from July 2002 to June 2011. His research investigates whether the relationships between the characteristics of stocks or companies and rates of return identified for developed markets also hold true for the Warsaw Stock Exchange. For portfolios, a correlation between a company's market capitalisation and the momentum factor (continuous capitalisation of past returns from t-12 to t-2) is noted regardless of the construction of the share portfolio. On the other hand, the ratio of the company's book value to its market value proves to be an important determinant in explaining the cross-sectional variability of returns. In the next stage, the author examines whether the Fama and French three-factor model is better suited to the data than the CAPM model. She has concluded that the three-factor model better explains the variability of rates of return for sorted portfolios based on the company's market capitalisation, the $\mathrm{B} / \mathrm{M}$ ratio and the reversal factor.
Waszczuk (2013) has contended that liquidity is not significantly related to the valuation of stocks. To diagnose whether this is caused by the lack of effect of solvency returns on the Warsaw Stock Exchange or maybe by the need to use a measure other than turnover for the Polish market, it is worth citing the article by Lischewski and Voronkova (2012). The purpose of their study has been a comprehensive analysis of the relationship between the three factors of Fama-French and liquidity and solvency and the rate of return on shares for companies listed on the Warsaw Stock Exchange in the period from January 1996 to March 2009. For the standard CAPM model, the statistical significance of free expression has been shown for most the portfolios. Beta coefficients prove to be positive and statistically significant. In the case of the Fama-French model, all factors turn out to be significantly different from zero and positive. Furthermore, the constant term shows statistical significance, which supports the authors' supposition that there is a factor that affects the rates of return and is not included in the model. An analysis of the results of portfolios sorted according to solvency shows that they differ significantly depending on the adopted solvency ratio. In addition, for the CAPM model, only three of the 50 constant terms are statistically significant, while in the case of the Fama-French model, $30 \%$ of the constant terms show statistical significance. The authors have concluded that solvency does not influence the rates of return of companies on the Warsaw Stock Exchange.

The articles presented above discuss a wide range of factors that may affect the rate of returns on equity as well as highlighting the broad scope of methodology that is used in this type of analysis. The predominant method is the theory of Fama-French and the two-step regression of Fama-MacBeth. A common feature of most of the studies outlined in this section is the consideration of the impact of a company's liquidity or solvency on returns on shares. The authors apply various measures to explore this phenomenon, but for most of the studies, it can be seen that taking into account such an estimator increases the explanatory power of the model. In the case of articles analysing the Warsaw Stock Exchange, an unambiguous relationship has not been identified, but it is still an evolving topic that is worth investigating as the stock market and the country's economy develop. Furthermore, augmenting the literature with an analysis of the impact of more liquidity and solvency ratios is still an open question. It seems particularly interesting to estimate the 
impact of estimators that have not yet been analysed on the rates of return on equity of companies listed on the Warsaw Stock Exchange with the help of the Fama and French factors.

\section{Analysis of the impact of liquidity and solvency on the rates of return of companies on the Warsaw Stock Exchange}

Based on the literature on the relationship between liquidity and solvency and the returns of companies listed on the Warsaw Stock Exchange, there is still room for further research. As mentioned earlier, although researchers have not yet identified an unambiguous relationship in this regard, such a relationship may still become established as the Warsaw Stock Exchange continues to develop and the country's economic system transforms. Medhat (2014) has proved that for companies listed on American stock exchanges, even the least-solvent firms still hold an amount of cash that is sufficient for them to settle their short-term liabilities. Poland is a less-developed market than the United States; however, it is described as the most developed one in its region. Therefore, it is interesting to check whether companies from the Warsaw Stock Exchange hold sufficient cash to cover their short-term liabilities, even at the highest level of insolvency. Hence, the first main hypothesis that we are going to test in this study states that companies at risk of bankruptcy are able to meet their shortterm obligations. Another hypothesis is related to the paper by Lischewski and Voronkova (2012), in which, based on non-financial liquidity and solvency measures, it has been found that these ratios do not have a significant impact on the returns of companies listed on the Warsaw Stock Exchange. Therefore, our second hypothesis states that liquidity and solvency measured by financial ratios significantly affect the sensitivity of the rate of returns on stocks to risk factors expressed in the CAPM, Fama-French and Carhart models. The conclusion by Lischewski and Voronkova (2012) is that the volatility of the results of asset valuation models depends on the adopted solvency or liquidity ratio. Therefore, taking into account the solvency and liquidity ratios that do not appear in the discussed literature and examining their impact on the rates of returns on equity of companies listed on the Warsaw Stock Exchange is certainly the distinguishing aspect of the study described in this paper.

The description of this study is divided into three parts. The first section contains the presentation of data and their preliminary analysis. The next part describes the deployed methodology. The last section contains the findings and conclusions of the research divided into two stages. The purpose of the first stage is to illustrate how the values of beta variables from the CAPM model change over time depending on the portfolios created on the basis of liquidity and solvency ratios. The second stage aims to examine the impact of risk factors included in the CAPM, Fama-French and Carhart models for portfolios built the same way.

\subsection{Data description}

This empirical study was conducted for companies listed on the Warsaw Stock Exchange in the period from 1 January 1999 to 30 June 2013. It required defining the risk-free rate and market index for Poland. In practice, most often, the risk-free rate is assumed as the yield on Treasury bonds or the inter-bank market rate (e.g. Warsaw Interbank Offer Rate [WIBOR]) (Jajuga and Jajuga, 2006). However, it should be remembered that even treasury securities are not riskfree, so when speaking about a risk-free rate, we must adopt the rate with the lowest possible risk at a given time among the various types of financial assets. This article adopts WIBOR3M as the risk-free rate. Additionally, the obtained results were confirmed against the profitability of 5-year or 10-year Treasury bonds. The market index is Warszawski Indeks Giełdowy (Warsaw Stock Exchange Index or WIG). ${ }^{7}$ The values of the factors MKT, SMB, HML and WML ${ }^{8}$ come from our own calculations conducted for the purpose of this article. The study used three liquidity ratios and four company solvency ratios (Table 1).

7 WIG is also used as a market index by Czapkiewicz and Wójtowicz (2014), Waszczuk (2013) and Lischewski and Voronkova (2012).

8 MKT - market factor at time $k$ in accordance with Fama and French (1992); SMB - company size factor at time $k$ in accordance with Fama and French (1992); HML - factor of a company's book value to its market value at time $k$ in accordance with Fama and French (1992); WML - the momentum factor at time $k$ in accordance with Fama and French (1992). 
Tab. 1: Definitions of liquidity and solvency ratios used in the empirical study

\begin{tabular}{ll} 
Solvency/liquidity ratio & Definition \\
\hline Quick ratio & $\frac{\text { Current assets - Inventory }}{\text { Current liabilities }}$ \\
\hline Current ratio & $\frac{\text { Current assets }}{\text { Current liabilities }}$ \\
\hline Net Working Capital Ratio & $\frac{\text { Current assets - Current liabilities }}{\text { Total assets }}$ \\
\cline { 2 - 2 } Leverage ratio & Total liabilities + Market value of equity \\
\hline Debt ratio & Total liabilities \\
\hline Altman Z-score & Total assets \\
& Z-Score $=6.56 * \frac{\text { Working capital }}{\text { Total assets }}+3.26 * \frac{\text { Retained earnings }}{\text { Total assets }}+$ \\
\hline Fixed asset coverage ratio & $\frac{\text { Equity capital }}{\text { Fixed assets }}$ \\
\hline
\end{tabular}

Source: Zalewska and Nehrebecka (2020).

The financial ratios were calculated on a quarterly basis from the data available on the Notoria website. ${ }^{9}$ The Stooq.pl website was the source of information on the rates of return. The rate of returns on stocks deployed in the study is the continuous rate of return, which was calculated daily in the first part of the study and on a quarterly basis in the second part of the study.

As a reminder, the first hypothesis is that companies at risk of bankruptcy are able to cover their short-term liabilities. The above hypothesis is verified by analysing the behaviour of the mean and median financial liquidity ratios according to the percentile of the solvency ratio (Figures 1-4). For each of the ratios (Altman $\mathrm{Z}$-score, the debt ratio, leverage ratio and fixed asset coverage ratio), changes in the current ratio, net working capital ratio and quick ratio are presented.

In the case of the Altman Z-score, the higher the value of the company, the lower is the risk of bankruptcy. As the probability of bankruptcy increases (i.e. Altman Z-score worsens), its financial liquidity deteriorates (Figure 1). ${ }^{10}$ Furthermore, if

9 Notoria Serwis S.A., http://www.notoria.pl

10 In Figure 2, a significant increase in the mean value of the quick and current liquidity ratios for the first Altman ratio quantile is noticeable, with no dramatic increase in the median. This means that there is a group of observations that are significant outliers within the first Altman ratio a company has a very high level of bankruptcy risk, it also has problems paying its short-term liabilities. This does not confirm the conclusions of Medhat's research in 2014, according to which even the most insolvent company is able to pay its short-term liabilities. However, this conclusion is consistent with the results of Acharya et al. (2012), who show that in the short term, an increase in the company's financial liquidity ratios has a significant positive impact on Altman Z-score.

In the case of the leverage ratio, the higher its value, the higher is the company's risk of bankruptcy. A firm's ability to repay short-term liabilities is similar to the Altman Z-score ${ }^{11}$ when it comes to the leverage ratio. An increased likelihood of a company going

quantile. However, this phenomenon does not occur for the liquidity net working capital ratio. It turns out that among the companies listed on the Warsaw Stock Exchange, there have been cases in history where the company had significantly higher current assets than short-term liabilities. An example is Atlantis S.A. in the second quarter of 2013, whose current assets were $149,000 \mathrm{zt}$ and short-term liabilities were at the level of 17,000 zł; or Sanwil Holding S.A. in the first quarter of 2013, whose current assets were 23,513,000 zł., while short-term liabilities were only 127,000 zł.

11 In this case also, as with Altman Z-score, there is a significant increase in the mean compared to the median value of the current and quick liquidity ratios in the first quantile of the leverage ratio. Explanation: see footnote 10 . 

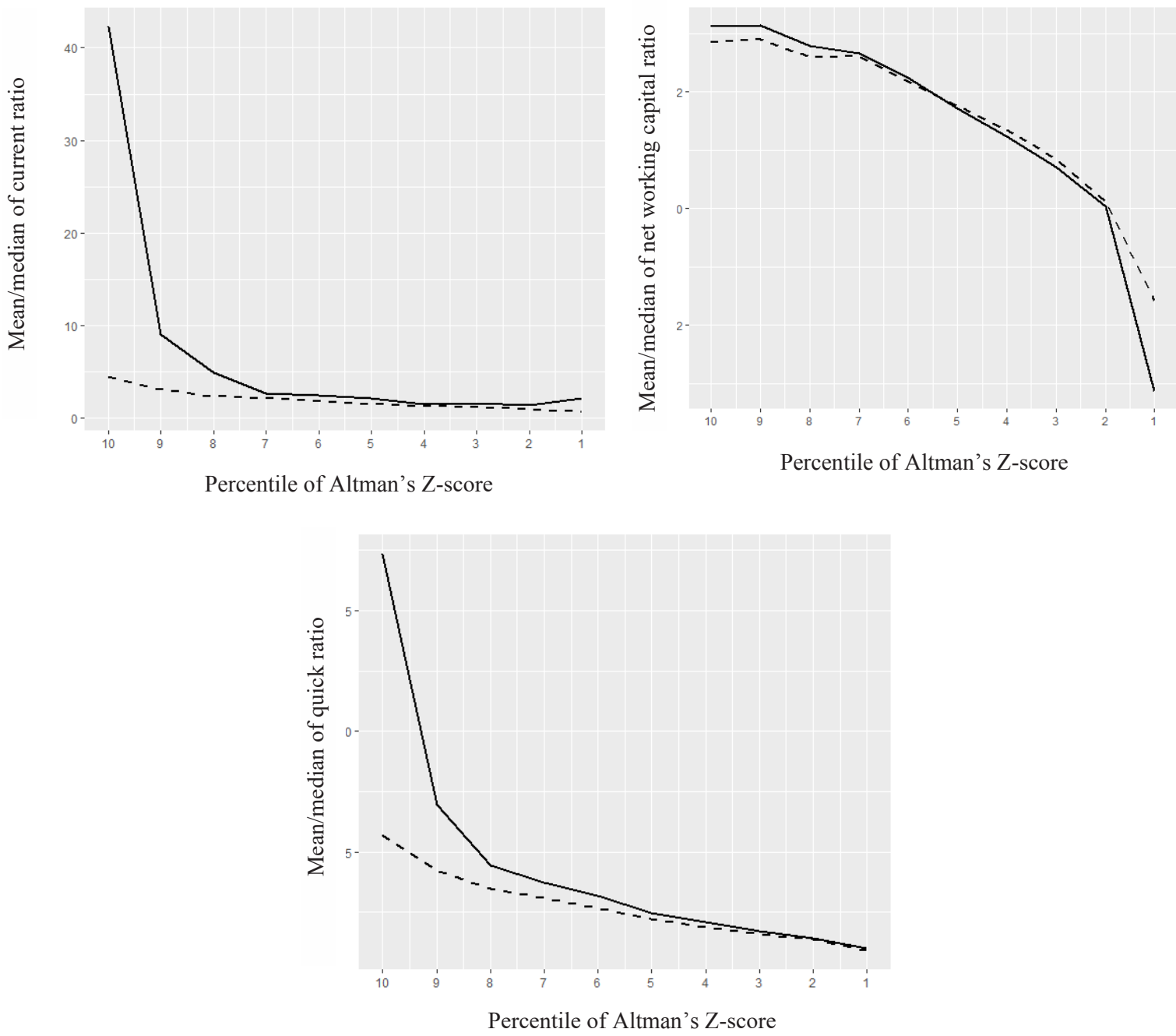

Fig. 1. Liquidity ratios and the Altman Z-score. Source: Zalewska and Nehrebecka (2020).

bankrupt also means problems with its financial liquidity. However, if the company has a very low level of bankruptcy risk, it is also able to repay its short-term liabilities. This supports the proposition formulated by Acharya et al. (2012), whereas the trend described in Medhat (2014) does not hold true for companies listed on the Warsaw Stock Exchange.

For the fixed asset coverage ratio, the following correlation is found. If it indicates a high risk of company bankruptcy, then we also observe a lower capacity of the company to pay short-term liabilities. ${ }^{12}$ This conclusion holds true irrespective of the measure used to assess the company's financial liquidity. This confirms the relationship noted in the analysis of

12 The disproportionate increase in the mean relative to the median for the quick and current liquidity ratios in the first debt ratio quantile is explained in footnote 39 .
Altman Z-score and the leverage ratio. The more solvency problems a company has, the less it is able to meet its short-term obligations. Similarly, based on the fixed asset coverage ratio, our results support the conclusions of Acharya et al. (2012); however, the correlation identified by Medhat (2014) has been rejected.

The debt ratio is a measure whose increase means a higher risk of bankruptcy. The relationship between a company's insolvency rate and its financial liquidity is negative. This means that a firm, which, based on an assessment of the debt ratio, was evaluated as having difficulty meeting long-term liabilities, would also be judged as likely to default on short-term liabilities. Once again, the relationship observed in Acharya et al. (2012) has been confirmed, while the calculations described in Medhat (2014) have not been supported. 

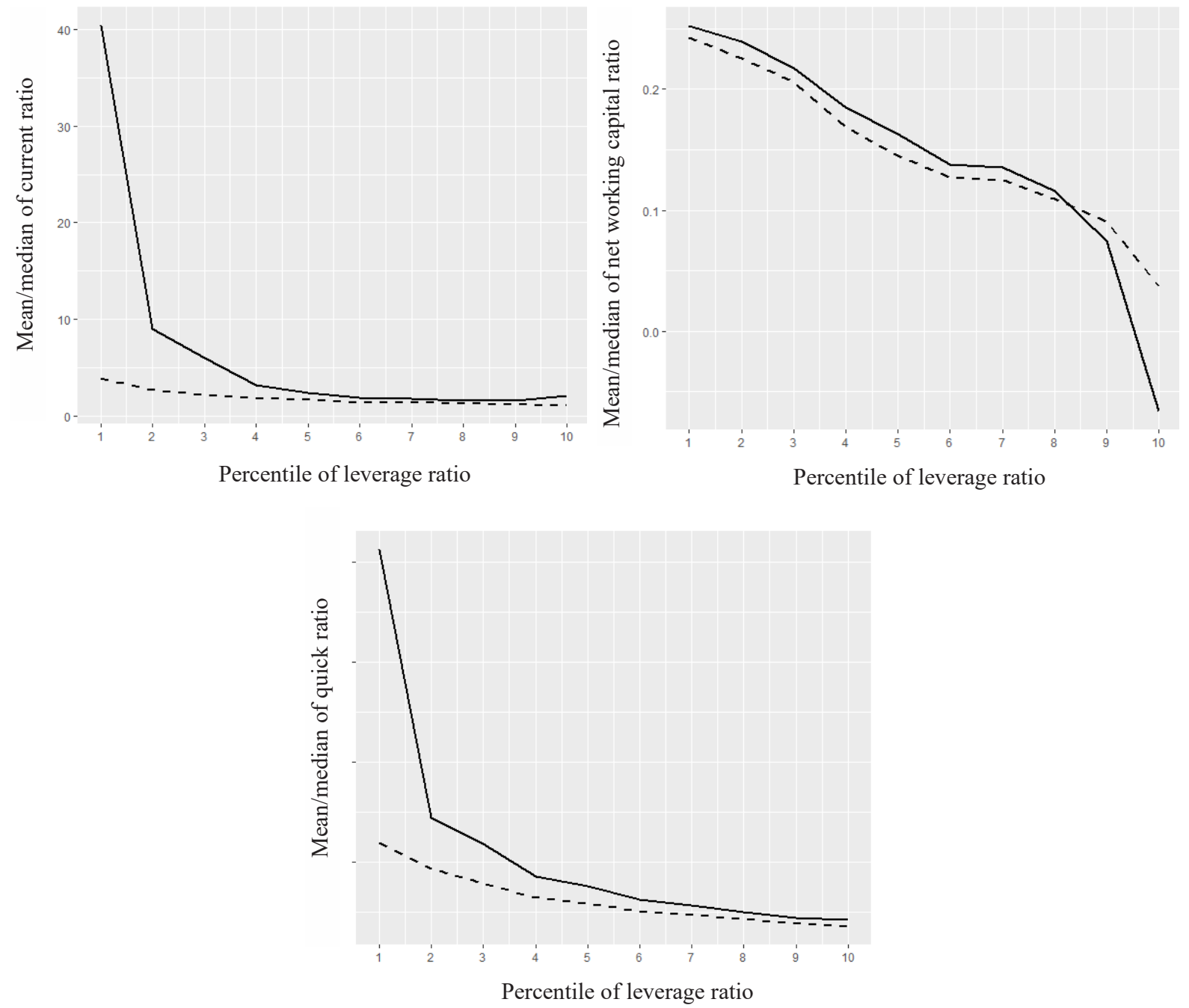

Fig. 2. Liquidity ratios and the leverage ratio. Source: Zalewska and Nehrebecka (2020).

To sum up, the relationship between solvency ratios and financial liquidity ratios is unambiguous. Low solvency of a company assessed by the measures debt ratio, Altman Z-score, the fixed asset coverage ratio and the leverage ratio also means a problem with the repayment of short-term liabilities, measured by the quick, current or net working capital ratio. Medhat (2014) shows a tendency for the liquidity measures to decrease along with the increase in the risk of company bankruptcy, however not to such an extent that the company would not still be able to meet its short-term obligations. In the case of companies listed on the Warsaw Stock Exchange, a negative relationship between the solvency ratios and liquidity ratios has been confirmed. The values of liquidity ratios for companies at risk of bankruptcy fall to a level that means a problem with the repayment of short-term liabilities.
The first main hypothesis of the study is that companies at risk of bankruptcy are able to settle their short-term obligations. Based on the analysis of the behaviour of average and median liquidity ratios across the company's solvency quantiles, we reject this hypothesis. The ability of an enterprise threatened by bankruptcy to meet its short-term obligations has not been identified for companies listed on the Warsaw Stock Exchange.

\subsection{Methods}

Two methods were used in the study: the least-squares method and quantile regression. In the classical form, the linear regression method involves estimating the conditional expected value of the explained variable. The basic formula is as follows: 

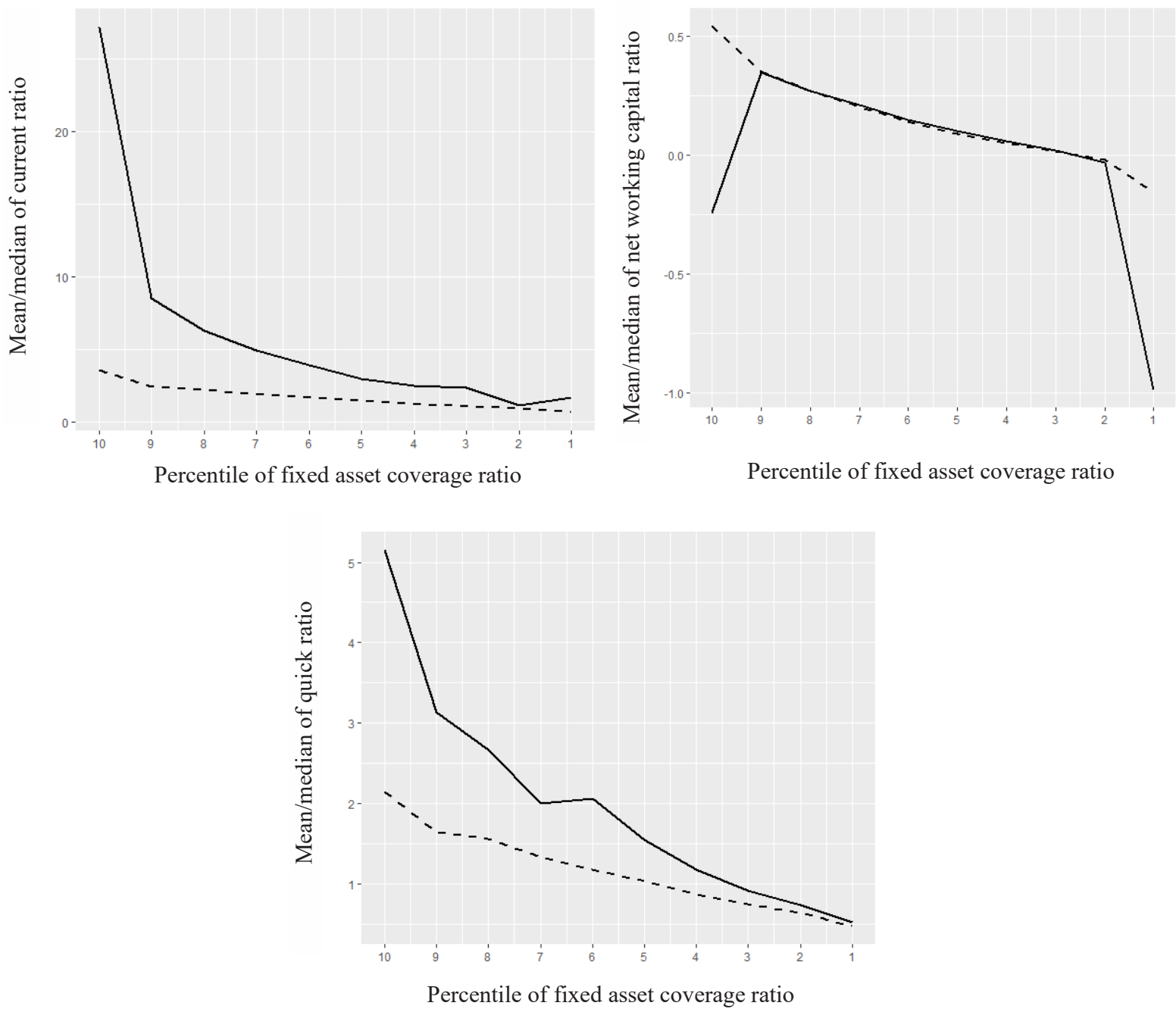

Fig. 3. Liquidity ratios and the fixed asset coverage ratio. Source: Zalewska and Nehrebecka (2020).

$E(y \mid x)=\varphi(x)$

where $y$ - explanatory variable, $x$ - matrix of values of explanatory variables, $E(y \mid x)$ - conditional expected value of the explanatory variable.

The least-squares method is most often used to estimate regression for the expected value. ${ }^{13}$ Its essence is approximating the estimators in such a way that the sum of squared deviations between the theoretical values of the explained variable and its empirical observation is as low as possible. Like any method, the least-squares method has its advantages

13 Based on the literature review, we find that the leastsquares method was used, for example by So and Tang (2010), Acharya et al. (2012), Minović and Živković (2012), Czapkiewicz and Wójtowicz (2014), Palazzo (2012) and Waszczuk (2013). and disadvantages. The weakness of the least-squares method is poor resistance to outliers in the sample.

In addition to the classical form of regression, there is also the concept of quantile regression, which aims at modelling the relationship between the quantum $\tau$ of the explained variable and the values of the explanatory variables, as described by Hallock and Koenker (2001). The conditional quantile $\tau$ of the explained variable can be written as follows:

$F_{y}\left(\xi_{\tau} \mid x\right)=\tau$

However, from the above equation, we can infer that

$\xi_{\tau}(x)=F_{y}^{-1}(\tau \mid x)$

Thus, quantile regression allows us to describe the dependence of the full distribution of the response 

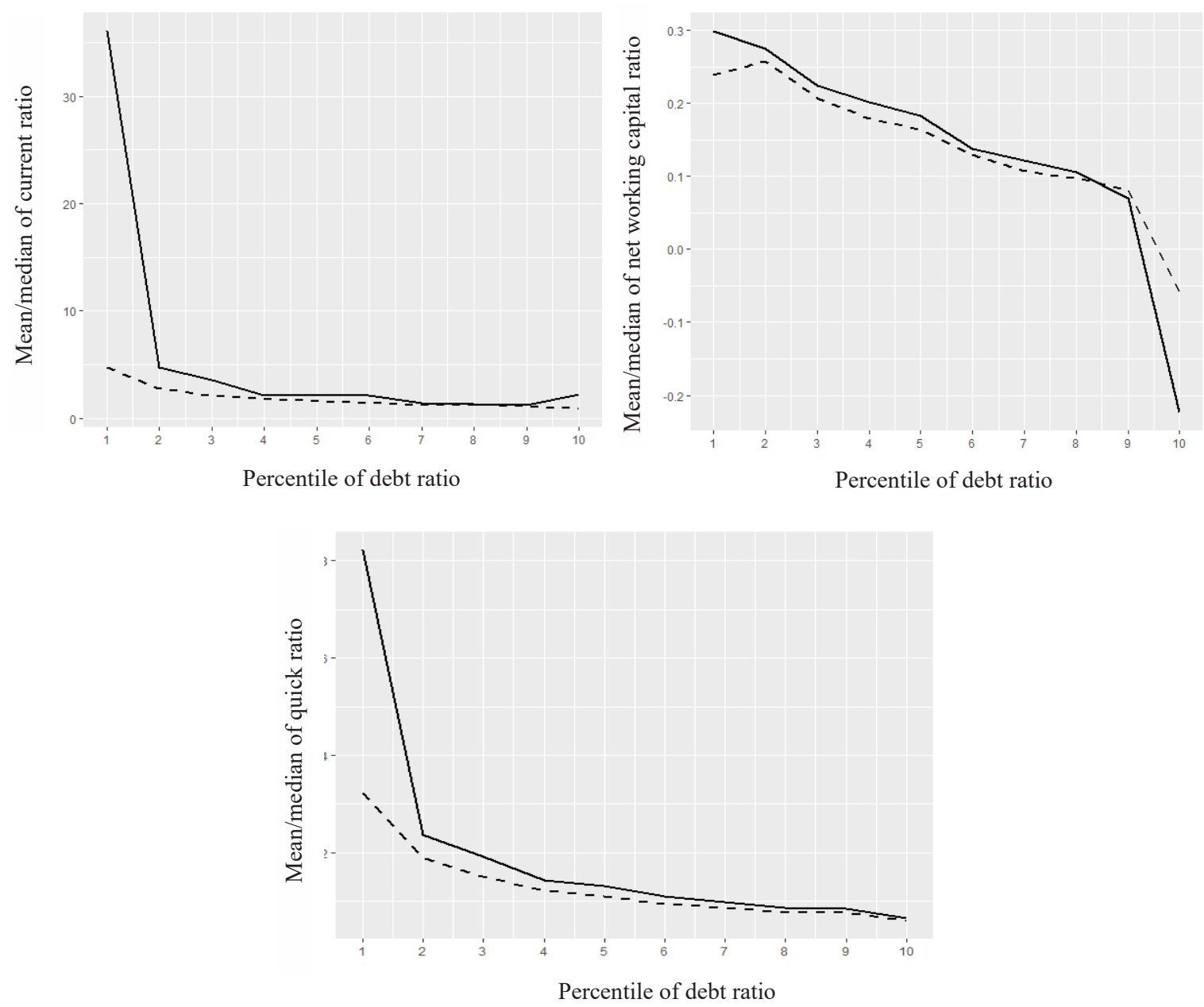

Fig. 4. Liquidity ratios and the debt ratio. Source: Zalewska and Nehrebecka (2020).

variable on the explanatory variables, while classic regression only models the expected value of the explained variable. The regression formula, therefore, depends on the modelled quantile.

In the case of quantile regression on the median, which was used in this empirical study, regression can be measured with the least absolute deviation (LAD) estimator. This method boils down to minimising the following objective function:

$\min \sum_{i=1}^{N}\left|y_{i}-\xi_{0,5}\left(x_{\mathrm{i}}, \beta\right)\right|$

Quantile regression has many benefits. The first one is lower sensitivity to outliers. In addition, quantile regression can be used regardless of the distribution of the remainder of the model because it is a semi-parametric method. The biggest drawback of quantile regression is the lack of formulas for variance and covariance in the obtained estimates, which translates into difficulties in verifying statistical hypotheses.

\subsection{Results}

This section presents a two-part empirical study. In the first stage, we determined time-varying beta coefficients and traced their behaviour depending on the percentiles of solvency and liquidity ratios. The second stage was the analysis of asset pricing models (CAPM, Fama-French and Carhart) for portfolios that were built based on solvency and liquidity ratios. The combination of conclusions from both these stages allows the verification of the second hypothesis. As a reminder, liquidity and solvency measured with financial ratios significantly affect the sensitivity of the rate of returns on shares to risk factors expressed in the CAPM, Fama-French and Carhart models. 


\subsubsection{The time-varying monthly beta estimators}

In the first stage of the empirical study, a CAPM model was evaluated for each company on daily data using the least-squares method. In total, 17,928 models were estimated. The assumptions made in this part of the analysis were as follows. The $\mathrm{b}$ coefficient ${ }^{14}$ may only be estimated when information on at least 10 rates of return was available for a given company in a given month. The validity of the results of the CAPM model was checked by the Breusch-Godfrey test for autocorrelation. The beta ratios estimated in this way were then adjusted according to the following formula:

$\beta_{\mathrm{i}, \mathrm{T}}^{\sim}=\mathrm{w}_{\mathrm{i}, \mathrm{T}} \beta_{\mathrm{i}, \mathrm{T}}^{\sim}+\left(1-\mathrm{w}_{\mathrm{i}, \mathrm{T}}\right) \beta_{\mathrm{T}}^{\prime}$

where $\beta_{T}$ - mean b-coefficient in a given month, $\beta_{i, T}^{\mathrm{i}}$ - b-coefficient of company $i$ in month $T, w_{i, T}=1-\frac{v_{i}^{2}}{v_{2}^{2}+v_{T}^{2}}, v_{T}^{2}$ variance of the $\mathrm{b}$-coefficient in month $T, v_{i}^{2}$ - variance of the b-coefficient for company $i$.

Next, the shares were sorted into portfolios according to liquidity ratio percentiles. The categorisation was done on a quarterly basis, which means that the observation of a given company in the first quarter of the year could be assigned to the first percentile of a given measure, while, in the next quarter, it could be assigned any other percentile. The portfolios are weighted by the market capitalisation of company $i$ at time $k$ in the sum of capitalisation of all companies taken into account at time $k$. For each of the portfolios created in this way, the mean and median of beta were determined. Figure 5 shows the outcomes of the first part of the empirical study. These graphs illustrate the variation of the beta coefficient depending on the percentile of the company's liquidity or solvency ratio. The solid line is the mean beta value. The dashed line represents the median for the corresponding percentiles. The analysis of the presented charts shows that, in contrast to the results of Medhat (2014) and Garlappi and Yan (2011) for companies listed on American stock exchanges, the relationship between the time-varying beta and a company's solvency is not unequivocal for companies

14 We are referring to the $\beta$-coefficient from the CAPM model interpreted as the value by which the rate of share or portfolio profit will increase on average if the stock index increases by one point. It is also determined by the measure of sensitivity of a given share or portfolio to market risk or the systematic risk indicator for a given investment. listed on the Warsaw Stock Exchange. For each of the solvency measures, no monotonic trend was found in the evolution of sensitivity to market risk depending on its percentile. Therefore, the conclusion presented in the article by Medhat (2014) about monotonic and decreasing function has not been confirmed for companies listed on the Warsaw Stock Exchange. In the study by Garlappi and Yan (2011), the beta coefficient first increased, reached a peak and then decreased along with the increase in the probability of company bankruptcy. There is no such relationship for companies from the Warsaw Stock Exchange. Similarly, in consistency with the findings of Waszczuk (2013) and Lischewski and Voronkova (2012), in our study, the beta coefficients from the CAPM model also turned out to be statistically significant and positive.

\subsubsection{Stock portfolio analysis}

In the second stage of the study, the following models were estimated for each of the portfolios created according to the procedure described above:

- CAPM formulated as follows: $R_{j, k}=\alpha_{j}+\beta_{j} * \mathrm{MKT}_{k}+\varepsilon_{j}$

- Fama-French formulated as follows: $R_{j, k}=\alpha_{j}+\beta_{j}^{\mathrm{MKT}} * \mathrm{MKT}_{k}+\beta_{j}^{\mathrm{SMB}} * \mathrm{SMB}_{k}+\beta_{j}^{\mathrm{HML}} * \mathrm{HML}_{k}+\varepsilon_{j}$

- Carhart formulated as follows:

$$
\begin{aligned}
& R_{j, k}=\alpha_{j}+\beta_{j}^{\mathrm{MKT}} * \mathrm{MKT}_{k}+\beta_{j}^{\mathrm{SMB}} * \mathrm{SMB}_{k}+ \\
& +\beta_{j}^{\mathrm{HML}} * \mathrm{HML}_{k}+\beta_{j}^{\mathrm{WML}} * \mathrm{WML}_{k}+\varepsilon_{j}
\end{aligned}
$$

where $R_{j, k}$ - difference between the rate of return on portfolio $j$ at time $k$ and risk-free rate at time $k$ MKT $_{k}$ - market factor at time $k$; $\mathrm{SMB}_{k}$ - company size factor at time $k ; \mathrm{HML}_{k}$ - company's book value factor to its market value at time $k$; $\mathrm{WML}_{k}$ - momentum factor at time $k$.

The methodologies used in this part of the study are the least-squares method and quantile regression. The database on the basis of which this part of the research was carried out contained quarterly data. In order to supplement the analysis of company asset pricing methods, the Sharpe ratio was calculated in the following form:

Sharpe $=\frac{R_{j, k}-\mathrm{Rf}_{k}}{\sigma_{R_{j, k}}}$ 
Altman's Z-score and monthly

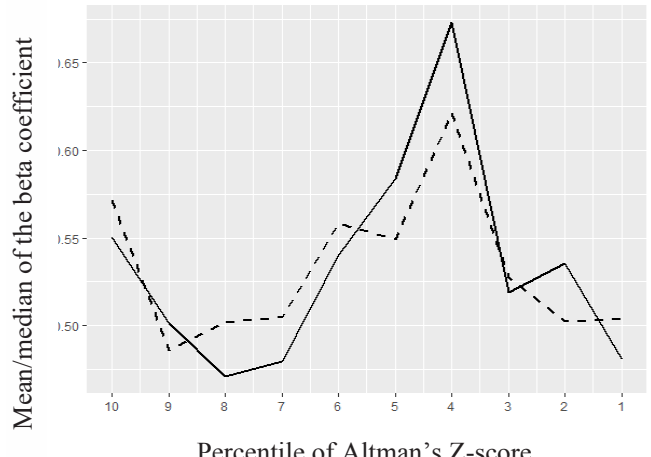

Percentile of Altman's Z-score

Leverage ratio and monthly beta

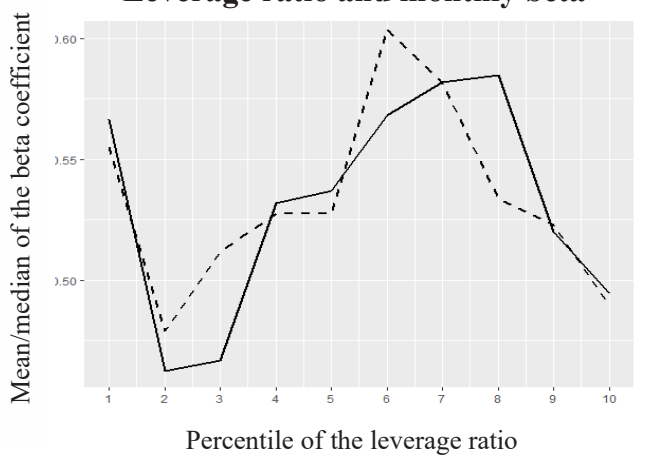

Fixed asset coverage ratio and monthly beta

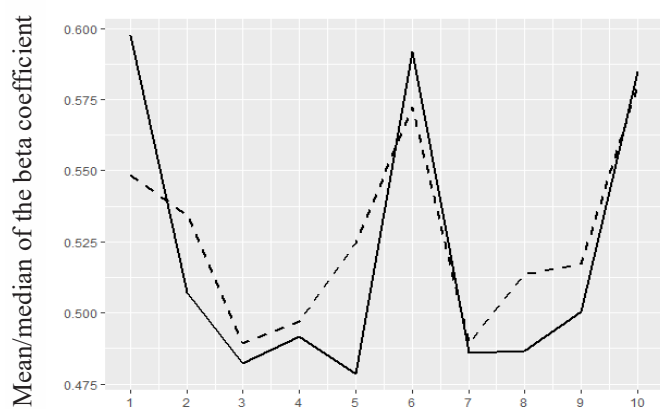

Percentile of the fixed asset coverage ratio

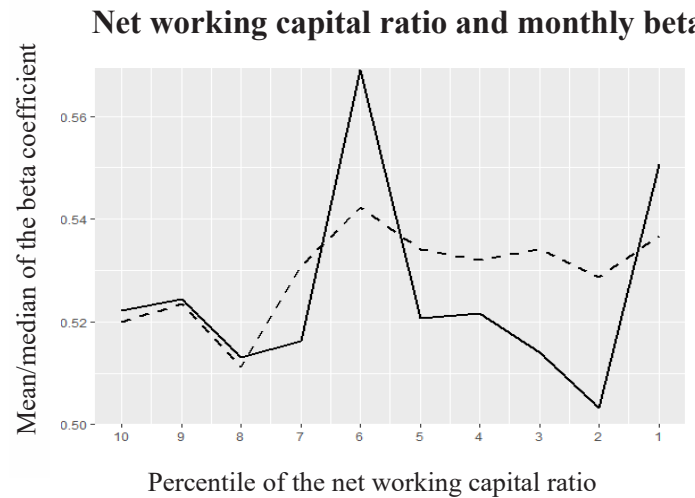

The quick ratio and monthly beta

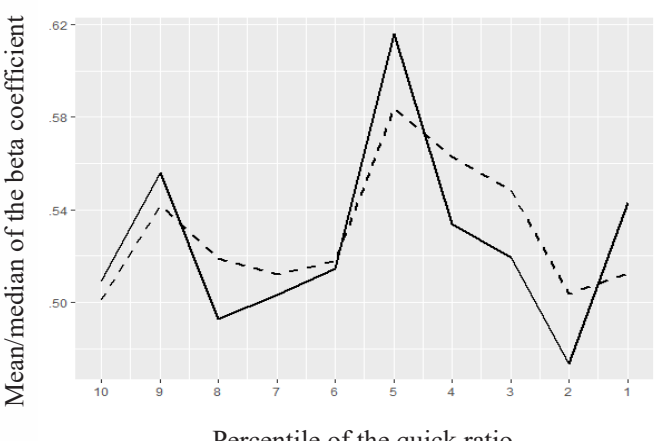

Debt ratio and monthly beta

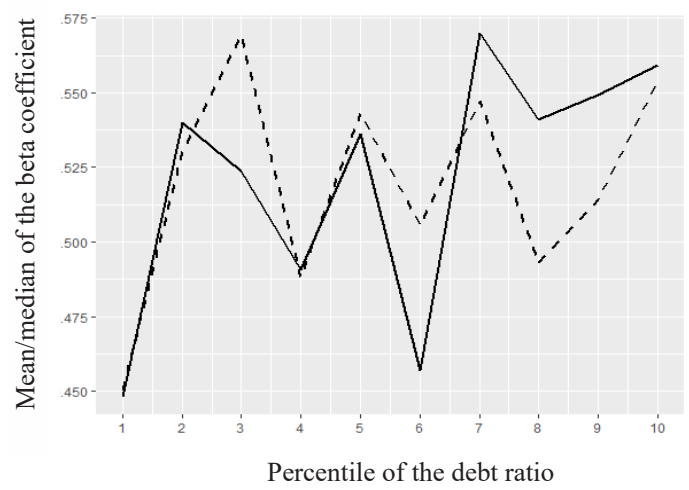

Fig. 5: Liquidity and solvency ratios versus monthly beta. Source: Zalewska and Nehrebecka (2020). 


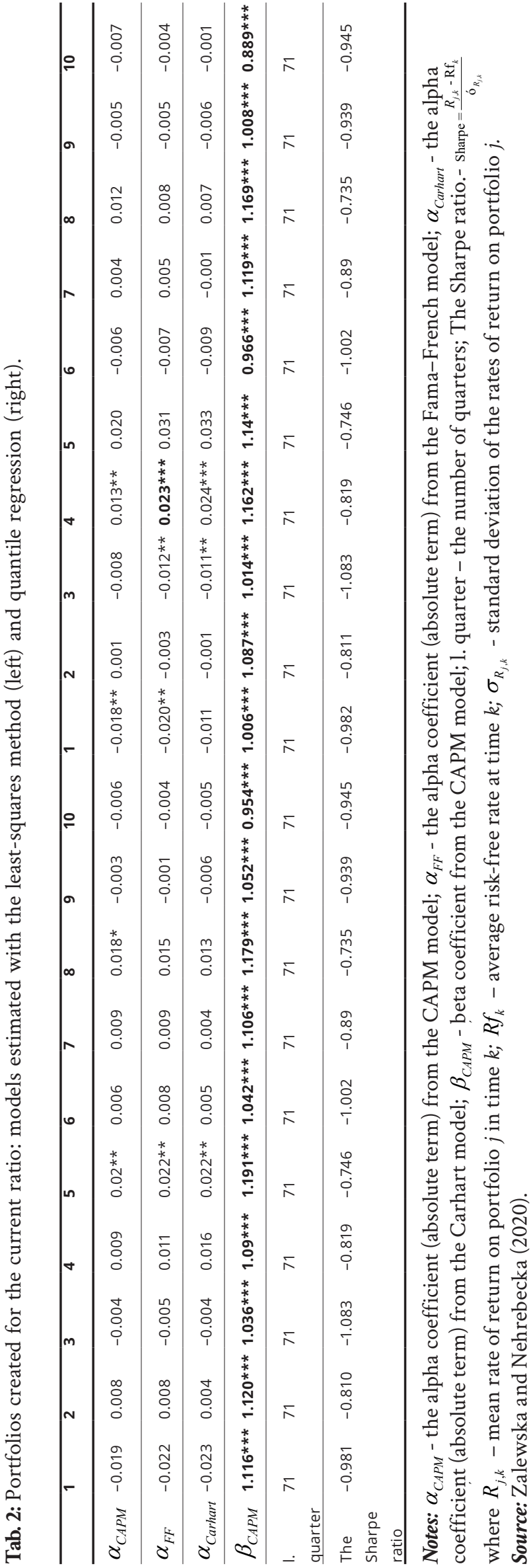

where $R_{j, k}$ - mean rate of return on portfolio $j$ in time $k ; R f_{k}$ - average risk-free rate at time $k ; \sigma_{R_{j, k}}$ standard deviation of the rates of return on portfolio $j$.

The Sharpe ratio (Patterson, 2011) allows us to assess whether the return on investment compensates for the risk incurred by the investor. It is the ratio of the difference between the average rate of return on investment and the average risk-free rate of return to the standard deviation of the rates of return on investment. Therefore, the higher this ratio is, the more favourable the investment should be.

Tables 2-8 show the results of the estimated models. For each measure, alpha coefficients from CAPM, Fama-French and Carhart models, the beta coefficient from the CAPM model and the Sharpe ratio were presented. On the left side of the table, we can see the results estimated by the least-squares method. On the right, there are the results of quantile regression.

The outcomes of this part of the analysis demonstrate that the beta coefficients from the CAPM model are positive, close to unity and statistically significant for each model for all liquidity and solvency ratios. In each case, they had values $>0.7$, and $76 \%$ of them were $>0.9$. However, as in the first step of the research, here also, no clear trend in the behaviour of beta depending on the percentile of the liquidity ratio or solvency of the company has been identified. Medhat's (2014) conclusion about the monotonic trend in beta values across liquidity portfolios has not been supported. Portfolios built on the basis of solvency ratios are, therefore, sensitive to market risk; their returns behave almost the same as, or even more than, the profit rate of the entire market. There is no monotonic (negative or positive) relationship between the increase or decrease in solvency and the level of company sensitivity to market risk.

As for the alpha coefficients, only four of them (9.5\%) are different from zero at the significance level of 0.05 . Moreover, a small percentage of significant ratios were identified for SMB, HML and WML risk factors. ${ }^{15}$ There were $14 \%, 29 \%$ and $21 \%$ coefficients different from zero, respectively, at the 0.05 significance level.

15 The SMB factor is a company size factor, $\mathrm{HML}$ is a factor associated with anomalies in the ratio of a company's book value to its market value, and WML is the so-called momentum factor. 


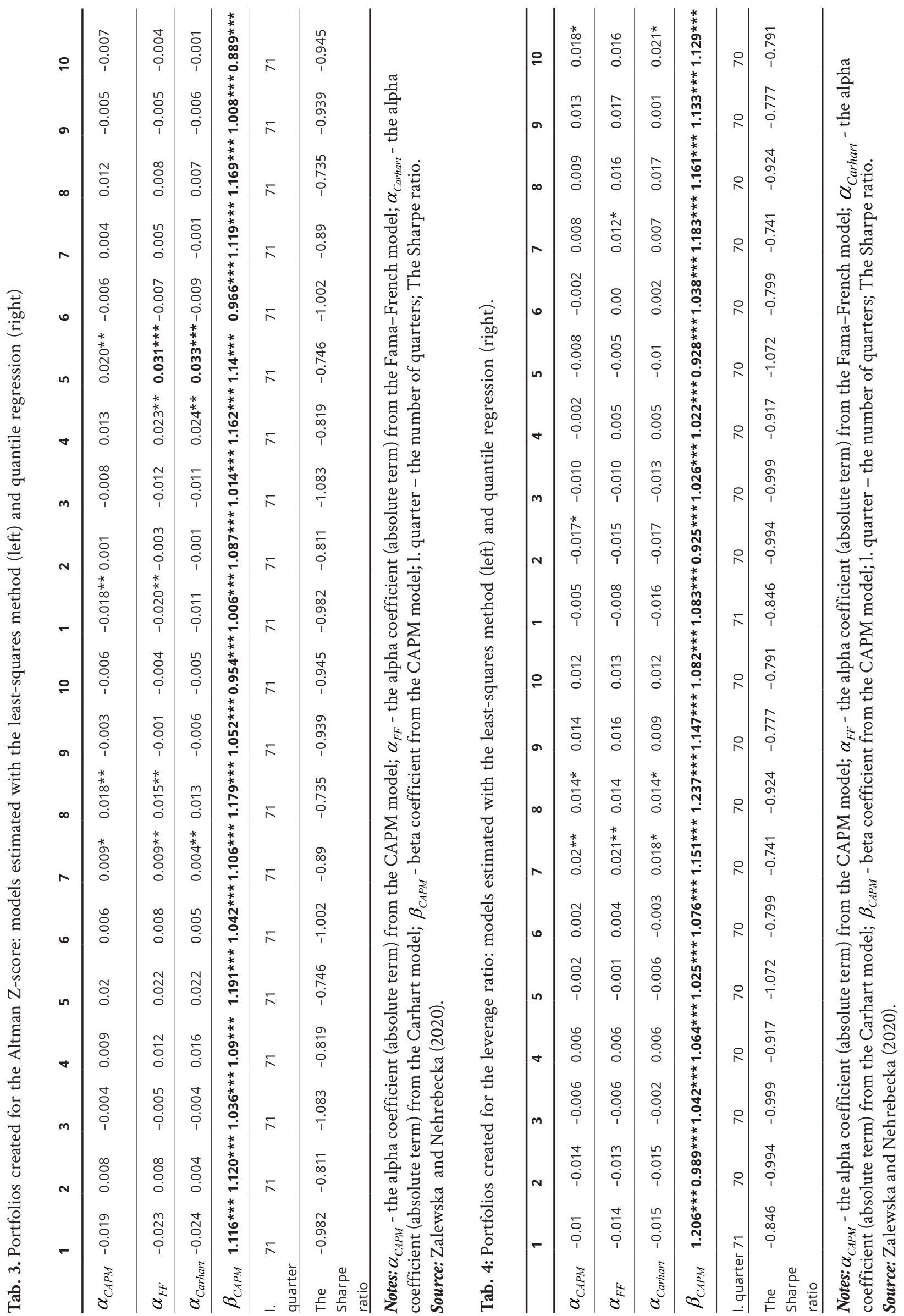




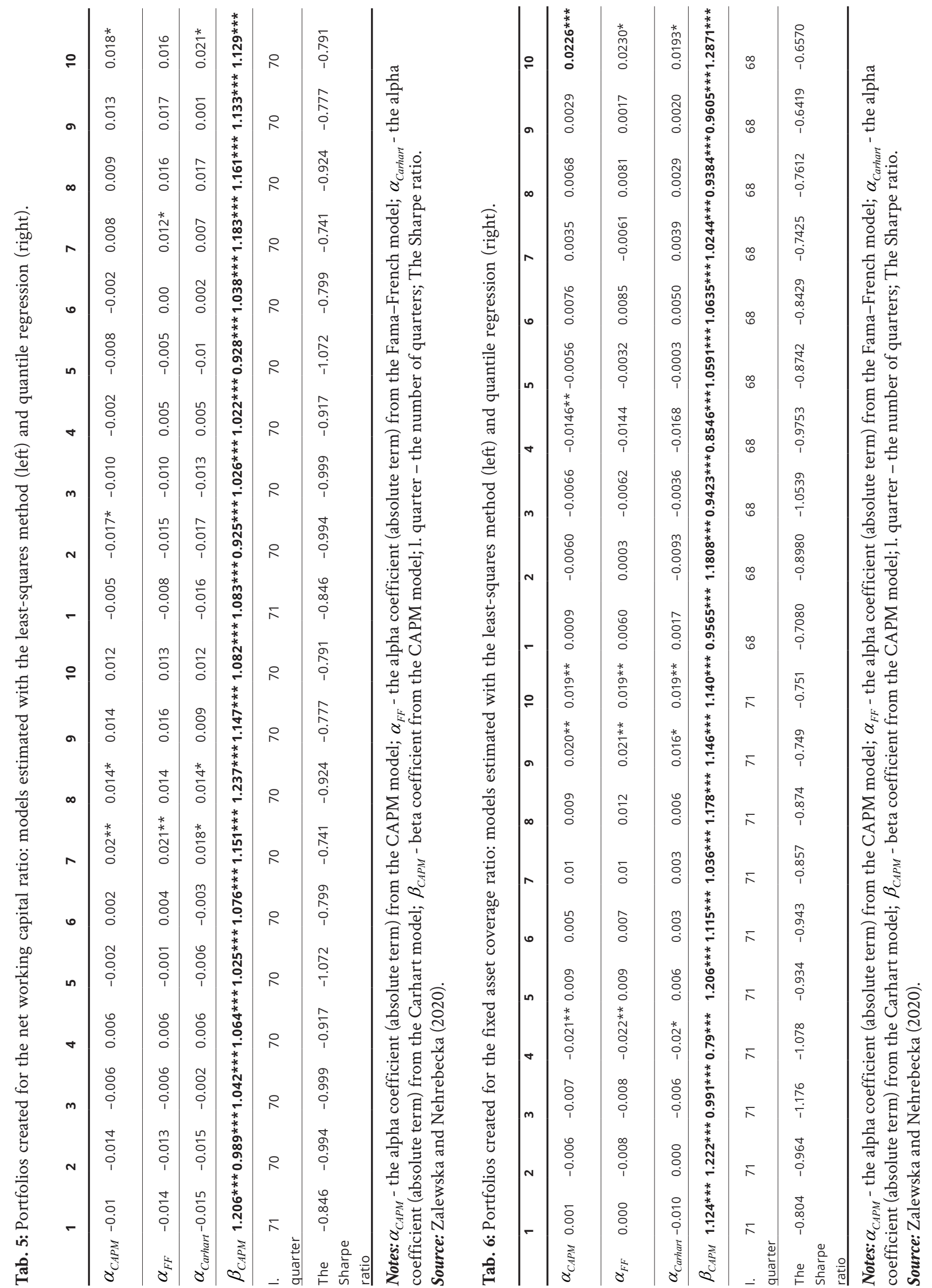




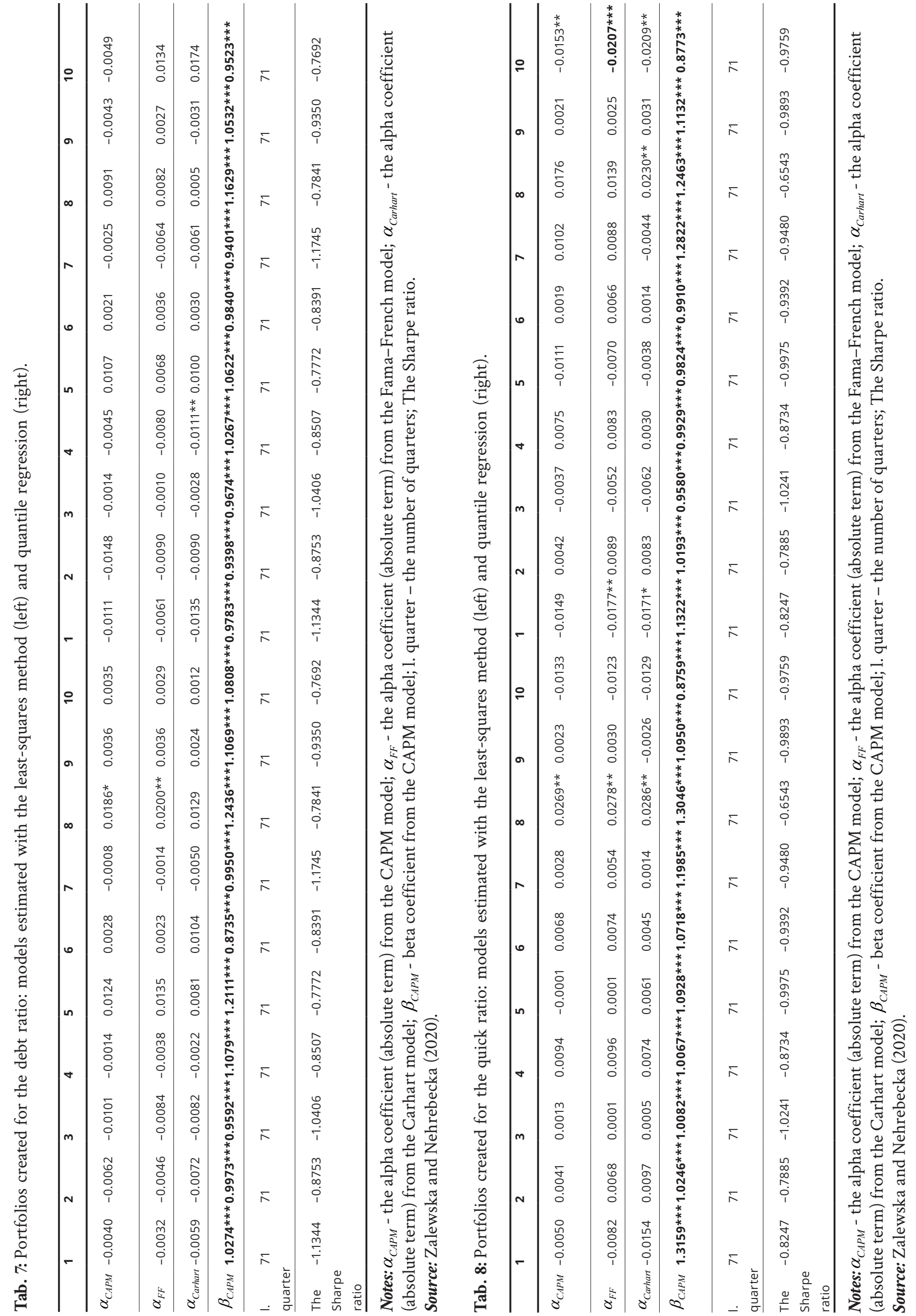


On the other hand, when it comes to matching the model to the data, the adjusted $R^{2}$ estimator for each of the liquidity and solvency ratios is the highest for the majority of portfolios for the Fama-French model. On the other hand, the Carhart model had the worst values. The total significance of the model parameters assessed by the $F$-test ${ }^{16}$ in each case suggests the rejection of the null hypothesis. This means that for each group of companies sorted according to liquidity or solvency ratios of companies listed on the Warsaw Stock Exchange, at least one of the risk factors expressed in the CAPM, Fama-French and Carhart model is significant. Most often, it is the MKT market risk factor.

TheSharpe ratio, regardless of the adopted solvency ratio, turned out to be negative for each portfolio. This means that portfolios based on the solvency ratio percentiles had a lower mean rate of return than the risk-free rate. The progression of changes in the value of this indicator does not show a clear trend. For all ratios except the asset coverage ratio, the Sharpe ratio is $<0.7$ for each portfolio. This observation points to a hypothesis that stock portfolios based on solvency ratios are not a good investment strategy.

The use of four solvency ratios and three company liquidity ratios to obtain a full picture of the company's condition instead of focusing on only one of the aspects was confirmed by the conclusion of Lischewski and Voronkova (2012) about different estimation results depending on the applied factor. The results change in terms of statistical significance of the sensitivity factors to the analysed risk factor as well as of their absolute values. On the other hand, the inference that there is no monotonic and explicit dependence of companies' sensitivity to risks expressed in the CAPM, Fama-French and Carhart models depending on the liquidity and solvency of the company remains valid.

Based on the above findings, we should reject the second hypothesis, according to which a company's sensitivity to risk defined in asset pricing models significantly depends on its liquidity and solvency determined by financial ratios. The analysis presented in this section does not support the conclusions of Medhat (2014) about the impact of liquidity expressed by the measures proposed by the researcher on the rate of returns on shares of companies listed on the

16 The $F$-test hypotheses are as follows. The null hypothesis is that each of the total model parameters is equal to zero. However, the alternative hypothesis assumes that at least one of the model parameters is different from zero.
Warsaw Stock Exchange. At the same time, the conclusion about the impact of liquidity on rates of return on shares on the Warsaw Stock Exchange propounded in the study by Lischewski and Voronkova (2012) is confirmed based on different liquidity ratios. Therefore, it seems that in the case of the Warsaw Stock Exchange, liquidity and solvency do not play such an important role in shaping returns as in other, more-advanced markets.

\section{Conclusions}

The purpose of our research was to analyse the impact of various financial measures assessing a company's liquidity and solvency on the rates of return on shares of companies listed on the Warsaw Stock Exchange. According to the literature review, there is a lot of research on the rate of returns on shares, which, as a factor shaping their volatility, takes into account liquidity or solvency in the form of various ratios. The first group of studies concerned the United States. The publications proved that the common opinion that companies with extensive cash resources are more solvent is not true. It was also shown that liquidity and solvency are important aspects in explaining the return on shares. The second group of analyses concerned less-developed but still advanced markets, such as Great Britain or Australia. The main conclusion was the significant impact of liquidity and solvency on returns on shares. The researchers concluded that the LCAPM model is better suited to the data than the standard CAPM. Analyses of emerging markets (such as Nigeria and Serbia) were also described. They do not provide unambiguous evidence about the importance of liquidity and solvency or lack thereof for these countries due to their specific characteristics. Research on Poland was also cited, in which no explicit relationship was identified. The results obtained in our study contribute to the development of knowledge in the discussed topic.

Our study verified two main hypotheses. The first main hypothesis stated that companies at risk of bankruptcy are able to meet their short-term obligations. It was rejected. In the case of Altman $\mathrm{Z}$-score, the leverage ratio, the fixed asset coverage ratio and the debt ratio, if they indicate a risk of bankruptcy, the quick, current and net working capital liquidity ratios signal a problem with the repayment of short-term liabilities. 
The second main hypothesis is that liquidity and solvency measured by financial ratios significantly affect the sensitivity of the rate of returns on shares to risk factors expressed in the CAPM, Fama-French and Carhart models. Based on the evolution of beta-time coefficients from the CAPM model and portfolio analysis, this hypothesis was rejected. No unambiguous relationship was identified between liquidity and solvency ratios on the one hand and the time-varying beta from the CAPM model, the risk estimators from the Fama-French and Carhart models, and the alpha coefficients from these models. There can be several reasons for this. According to Lischewski and Voronkova (2012), it may be the result of the liquidity support programme operating on the Warsaw Stock Exchange, the specific nature of the Polish economy (where small companies dominate on the stock exchange) or growing market liquidity. ${ }^{17}$ Identifying the reason for the described situation requires further research.

Based on our analysis, we did not check to what extent the individual aspects of a company's condition such as liquidity, solvency or net working capital are adapted to the realities of the Polish economy. Considering the fact that the selection of the liquidity or solvency ratio differentiates the results of asset pricing models, it would be necessary to analyse the suitability of the ratios available in the literature to the Warsaw Stock Exchange. This issue requires further analysis. In addition, it seems interesting to examine whether the LCAPM model is better suited to the data in the Polish market than the CAPM model, as Minović and Živković (2012) argue for the Serbian economy, Bradrania and Peat (2014) for the USA market or Li et al. (2014) for Japan.

\section{References}

Acharya, V., Sergei, A. D., Ilya, A. S. (2012). Cash holdings and credit risk. The Review of Financial Studies. 25(12), 3572-3609.

Amihud, Y. ,2002. Illiquidity and stock returns: cross-section and time-series effects. Journal of Financial Markets 5, 31-56.

17 Lischewski and Voronkova (2012) argue that the increase in wealth and savings can lead to greater investor activity on the stock market and, as a result, overall liquidity improvement.
Bali, T. G., Zhou, H. (2016). Risk, uncertainty, and expected returns. Journal of Financial and Quantitative Analysis. 51(3), 707-735.

Batten, J. A., Vo, V. X. (2014). Liquidity and return relationships in an emerging market. Emerging Markets Finance and Trade. 50(1), 5-21.

Bradrania, R. M., Peat, M. (2013). Liquidity and expected returns-Evidence from 1926-2008. International Review of Financial Analysis. 29, 10-23.

Bradrania, R. M., Peat, M. (2014). Characteristic liquidity, systematic liquidity and expected returns. Journal of International Financial Markets, Institutions and Money. 33, 78-98.

Chai, D., Viet, D., Vu, V. (2015). Empirical tests on the liquidity-adjusted capital asset pricing model. Pacific-Basin Finance Journal. 35, 73-89.

Chen, C.-M., Lee, H.-H. (2013). Default risk, liquidity risk, and equity returns: evidence from the Taiwan market. Emerging Markets Finance and Trade, 49(1), 101-129.

Cotter, J., O’Sullivan, N. Rossi, F. (2015). The conditional pricing of systematic and idisyncratic risk in the UK equity market. International Review of Financial Analysis. 37, 184-193.

Czapkiewicz, A., Wójtowicz, T. (2014). The fourfactor asset pricing model on the Polish stock market. Economic Research-Ekonomska Istraživanja, 27(1), 771-783.

Dębski, W. (2014). Rynek finansowy $i$ jego mechanizmy. Podstawy teorii $i$ praktyki. Warszawa: PWN.

Fama, E. F., French, K. R. (1992). The cross-section of expected stock returns. The Journal of Finance. XLVII(2), 427-465.

Friewald, N., Wagner, C., Zechner, J. (2014). The cross-section of credit risk premia and equity returns. The Journal of Finance. LXIX(6), 2419-2469.

Gabrusiewicz, W. (2014). Analiza finansowa przedsiębiorstwa. Teoria i zastosowanie. Warszawa: PWE.

Garlappi, L., Yan, H. (2011). Financial distress and the cross-section of equity returns. The Journal of Finance. LXVI(3), 789-822.

Hallock, K. F., Koenker, R. (2001). Quantile regression. Journal of Economic Perspectives. 15(4), 143-156. 
Hearn, B. (2014). Size and liquidity effects in Nigeria: And industrial sector study. The Journal of Developing Areas, 48(3), 1-30.

Holden, C. W., 2009. New low-frequency spread measures. Journal of Financial Markets 12, 778-813.

Huffman, S. P., Moll, C. R. (2012). An examination of the relation between asymmetric risk measures, prior returns and expected daily stock returns. Review of Financial Economics. 22, 8-19.

Jachna, T., Sierpińska, M. (2004). Ocena przedsiębiorstwa wedlug standardów światowych. Warszawa: PWN.

Jajuga, K., Jajuga, T. (2006). Inwestycje. Instrumenty finansowe, aktywa niefinansowe, ryzyko finansowe, inżynieria finansowa. Warszawa: Wydawnictwo Naukowe PWN.

Li, B., Sun, Q., Wang, V. (2014). Liquidity, liquidity risk and stock returns: evidence from Japan. European Financial Management. 20(1), 126-151.

Lischewski, J., Voronkova, S. (2012). Size, value and liquidity. Do they really matter on an emerging stock market? Emerging Markets Review. 3, 8-25.

Liu, W. (2004). Liquidity premium and a two-factor model.EFA 2004 Maastricht Meetings Paper, No. 2678.

Medhat, M. (2014). Liquidity risk and distressed equity, Job Market Paper for the 2015 Academic Job Market.

Minović, J., Živković, B. (2012). The impact of liquidity and size premium on equity price formation in Serbia. Economic Annals. LVII(195), 43-78.

Palazzo, B. (2012). Cash holdings, risk, and expected returns. Journal of Financial Economics. 104(1), 162-185.

Park, J. L. (2015). Equity returns of distressed equity issuers. Finance Research Letters. 14, s93-103.

Patterson, R. (2011). Kompendium terminów z zakresu finansów po polsku i angielsku. Kraków: Wydawnictwo Zielona Sowa.

So, S. M. S., Tang, G. Y. N. (2010). An examination of conditional effect on cross-sectional returns: Singapore evidence. Applied Economics. 42, 777-795.

Wang, F. (2012). Idiosyncratic corporate liquidity and equity returns. Banking and Finance Review. 2, 47-70.
Waszczuk, A. (2013). A risk-based explanation of return patterns - Evidence from the Polish stock market. Emerging Markets Review. 15, 186-210. 